\title{
Removal of chromium VI and others metals from wastewater treatment by modification of macrophytes and magnetite: A review
}

\section{Márcio da Costa Nogueira ${ }^{1}$, Edson Rodrigo Fernandes dos Santos $^{2}$, Kaushik Pal ${ }^{1}$ and Fernando Gomes de Souza Júnior ${ }^{1}$}

${ }^{1}$ Universidade Federal do Rio de Janeiro. Instituto de Macromoléculas Professora Eloisa Mano. Laboratório de Biopolímeros e Sensores. Avenida Horácio Macedo 2030. Bloco J. Centro de Tecnologia. Cidade Universitária. Rio de Janeiro-RJ, Brazil (CEP 21941-598). *Email: profnogueira@yahoo.com.br.

${ }^{2}$ Bio Scie Indústria e Comércio LTDA. Laboratório de Controle de Qualidade. Viela Vp-7D. Distrito Agroindustrial, Anápolis-GO, Brazil (CEP 75132-140).

Abstract. One of the problems that affect the environment is the chemical pollution of the nature of the water, mainly by the presence of toxic metals, among them the chromium, copper, nickel, zinc, among others. Numerous studies report the application of biosorption with the use of Eichhornia crassipes for the treatment of effluents from diverse origins, with very satisfactory results. However, several factors influence biosorption, such as $\mathrm{pH}$, temperature, and contact time, and, therefore, cannot be neglected. Submerged macrophytes have important prospective to bioconcentrate heavy metals due to their larger surface area compared to non-submerged plants. On the other hand, the magnetite nanoparticles also present good results for the treatment of aqueous solutions contaminated by chromium and by other metal ions. The adsorption capacity of the $\mathrm{Fe}_{3} \mathrm{O}_{4}$ nanoparticles is high for various metal cations. Besides, these nanoparticles, which constitute polymer nanocomposites, are of particular interest because they combine excellent magnetic properties, greater stability of magnetic nanoparticles, and have higher biocompatibility, allowing more excellent suitability with biological materials involved in the removal of metallic cations. Therefore, the treatments described in this study are of great relevance as excellent alternatives in the treatment of several types of effluents.

Keywords: Eichhornia crassipes; Chromium; Toxic metals; Adsorption; Nanocomposites.

Resumo. Remoção de cromo hexavalente e de outros metais presentes em efluentes por tratamentos com macrófitas modificadas e magnetita: uma revisão. Um dos problemas que afetam o meio ambiente é a poluição química da água,

Received

September 4, 2020

Aceito

November 28, 2020

Available online November 30, 2020

Released

December 31, 2020

Full Text Article

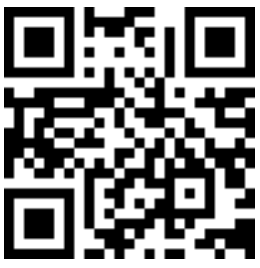

ORCID

0000-0003-4762-2395

Márcio da Costa

Nogueira

D) 0000-0003-3269-3318

Edson Rodrigo

Fernandes dos Santos

0000-0002-9313-6497

Kaushik Pal

ISSN 2359-1412/RBGAS-2020-0134/2020/7/17/25/1439

Rev. Bras. Gest. Amb. Sustent.

http://revista.ecogestaobrasil.net 
principalmente pela presença de metais tóxicos, entre eles o cromo, cobre, níquel, zinco, entre outros. Inúmeros estudos relatam a aplicação da biosorção com o uso de Eichhornia crassipes para o tratamento de efluentes de diversas origens, com resultados muito satisfatórios. No entanto, vários fatores influenciam a biosorção, como $\mathrm{pH}$, temperatura e tempo de contato, e, portanto, não podem ser negligenciados. As macrófitas submersas têm uma perspectiva importante para bioconcentrar metais pesados devido à sua maior área de superfície em comparação com plantas não submersas. Por outro lado, as nanopartículas magnetitas também apresentam bons resultados para o tratamento de soluções aquosas contaminadas por cromo e por outros íons metálicos. A capacidade de adsorção das nanopartículas $\mathrm{Fe}_{3} \mathrm{O}_{4}$ é alta para vários cátions metálicos. Além disso, essas nanopartículas, que constituem nanocompósitos de polímeros, despertam um grande interesse porque combinam excelentes propriedades magnéticas, maior estabilidade das partículas magnéticas, e possuem uma maior biocompatibilidade, permitindo uma maior adequação com materiais biológicos envolvidos na remoção de cátions metálicos. Sendo assim, os tratamentos descritos neste trabalho são de grande relevância como excelentes alternativas no tratamento de diversos tipos de efluentes.

Palavras-chave: Eichhornia crassipes; Cromo; Metais tóxicos; Adsorção; Nanocompósitos.
D 0000-0002-8332-4953

Fernando Gomes de

Souza Júnior

\section{Introduction}

Water is primary for the survival of all the species of life on planet Earth. However, this valuable natural resource is getting scarce on the planet, due principally to the agricultural and industrial sectors, as a consequence of the exponential increase of the world population. The wastewater created in industries is responsible for the release of many toxic metals into the environment, which pose a danger several ecosystems. Among the heavy metals, chrome is known for its high toxicity and for being carcinogenic (Kong et al., 2014).

One of the problems affecting the environment is the chemical pollution of organic and/or inorganic nature, mainly due to the increase of industrial activity, deteriorating the ecosystems by the accumulation of toxic metals in industrial effluents. Aquatic pollution, one of the most serious, causes changes in the physical, chemical, and biological characteristics of the waters, which interfere in their quality. Toxic metals are very harmful to the environment and human health due to their bioaccumulation capacity and the high time of permanence in the environment (Jimenez et al., 2004).

The electro coagulation process involves the creation of metal hydroxides in water from electrode dissolution processes as described in Figure 1. In addition, this process has two sequential steps, such as the formation of coagulants and also the metal reduction from hexavalent chromium to trivalent chromium. 


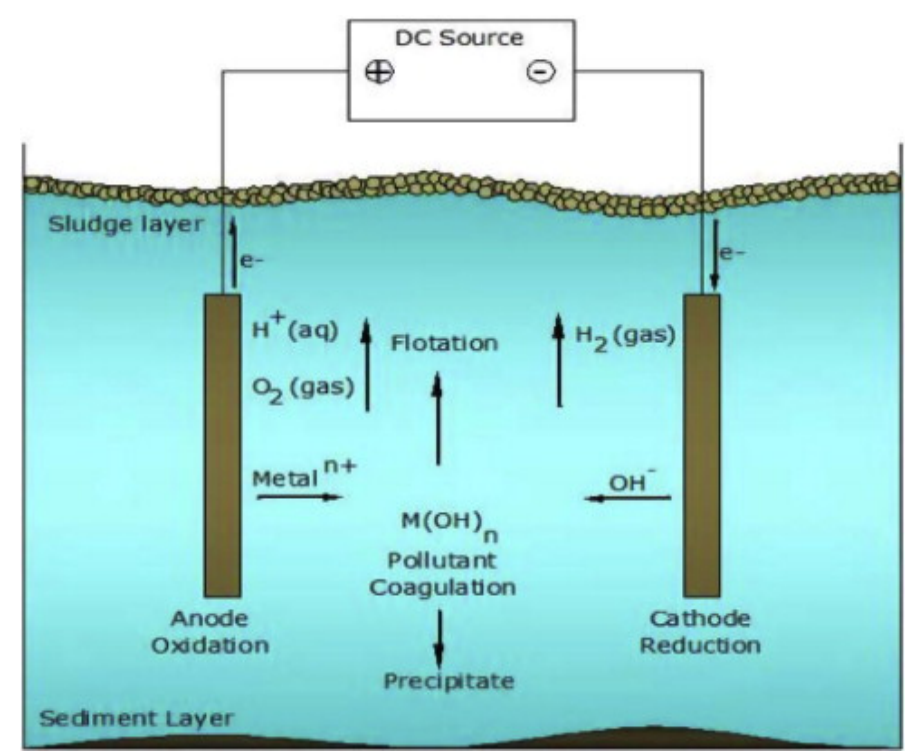

Figure 1. Schematic representation of bench-scale two-electrode electro coagulation system of waste water treatment (El-Taweel et al., 2015) (Copyright (C) 2015, Egyptian Journal of Petroleum).

Hexavalent chromium (VI), for example, has been used by the electronics industry as corrosive treatment, in addition to other applications such as zinc bath parts, integrated circuit boards, and cathode-ray tubes, as well as for shielding for some components. A restricted number of $\mathrm{Cr}(\mathrm{VI})$ compounds is known. They are powerful oxidant agents and comprise the chromates $\left[\mathrm{CrO}_{4}\right]^{2-}$, the dichromates $\left[\mathrm{Cr}_{2} \mathrm{O}_{7}\right]^{2-}$, tri [chromium oxide], $\mathrm{CrO}_{3}$, oxi-halides $\mathrm{CrO}_{3} \mathrm{X}^{-}$and $\mathrm{CrO}_{2} \mathrm{X}_{2}, \mathrm{CrOX}_{4}$ and $\mathrm{CrF}_{6}$ (Lee, 1999).

On the other hand, this same chromium and other transition metals are indispensable for life, but are toxic at large concentrations. Figure 2 shows the structure of a chrome complex, which currently appears as one of the most important and most popular nutritional supplements marketed in the world. This compound has been used in obesity treatments and muscular strengthening and was also recommended in type II diabetes therapies (Shadreck and Mugadza, 2013).

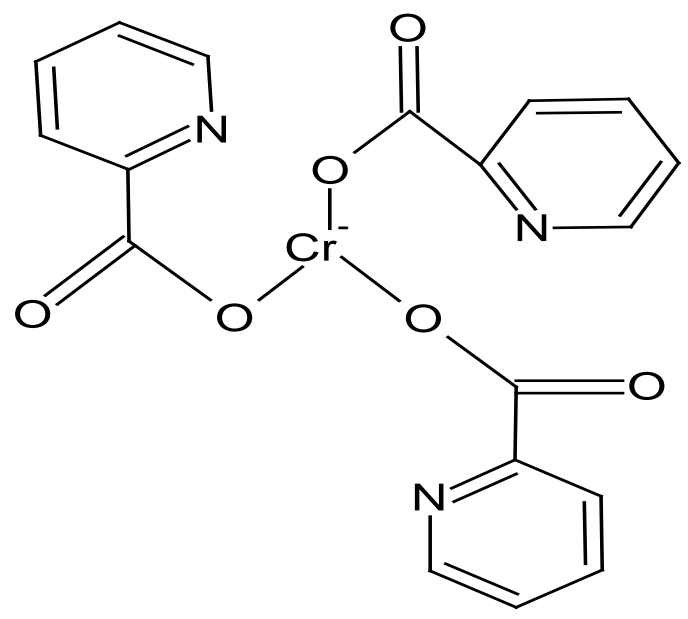

Figure 2. Structure of chrome (III) tripicolinate (own elaboration). 
The toxicity of the Cr (III) ion is negligible compared to that of the Cr (VI) ion. Nevertheless, there are some nutricional supplements based on chromium picolinate that contains the $\mathrm{Cr}$ (III) ion, which can be sufficiently toxic to human cells (Preuss et al., 2008) (Santander et al., 2017).

Considering that chromium has a high potential for environmental degradation, mainly in its hexavalent form, the objective of this work is to introduce a review on the efficiency of the removal of chromium VI and other toxic heavy metals present in Aquatic environments, from the use of macrophytes, as well as investigating the efficiency of treatment with modified macrophytes, in the performance of cation removal, such as chromium, copper, nickel, zinc, among others.

\section{Materials and methods}

For the bibliographic review, searches were performed in the Web of Science database, using the following search terms "metal removal", "Eichhornia crassipes", "magnetite", "chromium", "toxic metals adsorption", "nanocomposites" and "metal removal with polymers". The survey was conducted between June 2019 and January 2020. The articles published from 2004 to 2019 were selected, with special attention to the most recent works published between 2015 and 2019.

\section{Results and discussion}

Forty-two references were selected in this review. The chosen works address, in a very broad way, this very relevant theme, especially for the preservation of the environment. The results show that it is possible to remove metals from effluents by using less environmentally aggressive methods, such as the application of biomasses in the process. Removal results above $70 \%$ were found frequently, which shows that this technique should not be discarded. On the contrary, studies on the subject should be stimulated, aiming at an improvement of this type of effluent treatment, especially of industrial effluents that, for the most part, contains significant concentrations of toxic metals. In addition, the chemical modification of biomasses represents a great possibility of increasing the efficiency of biological processes for the removal of toxic substances present in water, such as heavy metals like copper, chromium lead, nickel among others. In this work, applications of some types of biomass and magnetite are being cited for the removal of metal ions present in water.

\section{Biosorption}

Several types of biomass, such as microorganisms, plants, and some agricultural or industrial by-products such as bark, bagasse, and seeds, can retain metal ions by adsorption (Rodrigues et al., 2006). The variables that have a more significant influence on the process of metal biosorption should be tested with variations around the best metal removal level by biomass. The most important factors that should be considered are the initial concentration of biomass and metal, reaction time, degree of agitation, application of a pre-treatment, and $\mathrm{pH}$ (Kłos et al., 2014). Indeed, magnetic nanosphere were employed to remove metal ions from waste water as shown in Figure 3 (Kumari et al., 2015), reported in this review. 


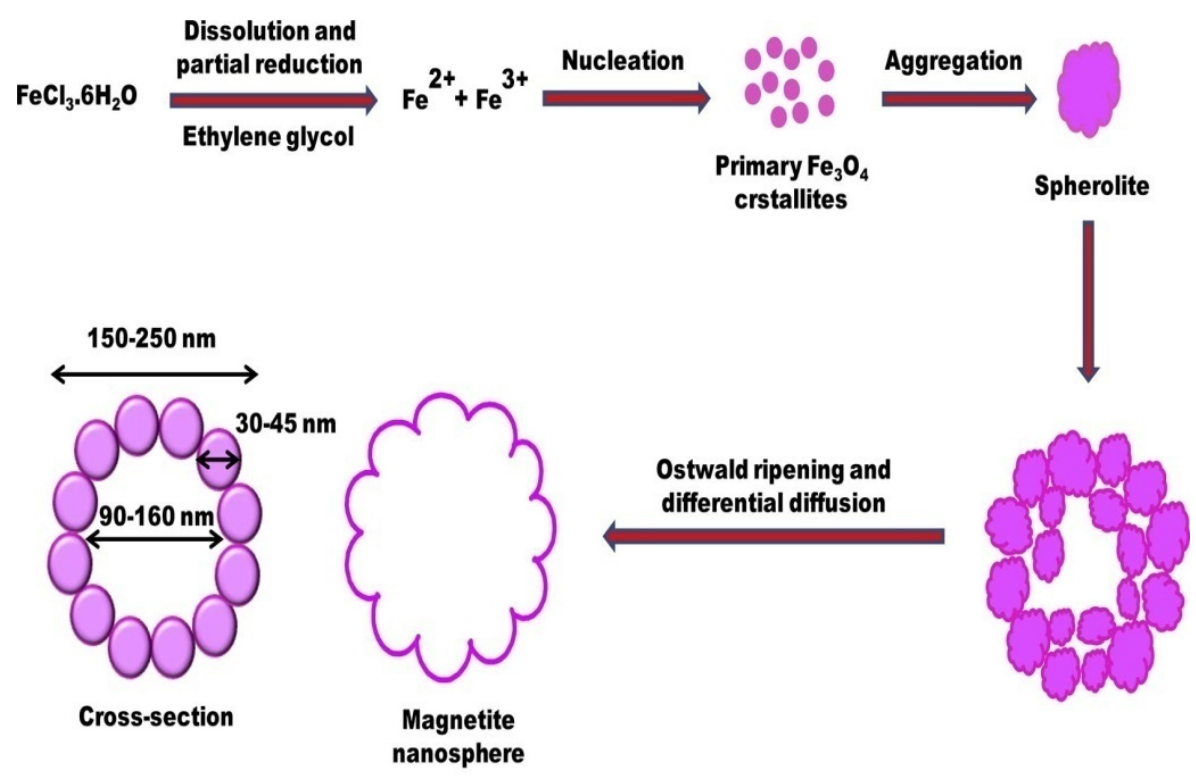

Magnetite nanospheres formation and evolution

Figure 3. Magnetic nanosphere formation and evaluation (Kumari et al., 2015) (Copyright (C) 2015, Elselvier).

In the treatment of water contaminated with heavy metals, there is the possibility of the application of numerous technologies, among them adsorption, biosorption, coagulation-flocculation, chemical precipitation, ion exchange, advanced oxidative processes and membrane separation processes. However, among the mentioned techniques, biosorption is the most economical, efficient and widely accepted process, considering that biosorbent materials are ecological, available in large quantities and, in general, do not produce by-products after treatment (Bind et al., 2018).

However, the $\mathrm{pH}$ factor is one of the most critical parameters in the process of biosorption of toxic metals since the number of active sites on the surface can change depending on this value. Adsorption is favored as the $\mathrm{pH}$ is increased. This behavior suggests the adsorption of metallic ions by the hydroxyl $(-\mathrm{OH})$ and carbonyl $(\mathrm{C}=0)$ groups present in the chemical structure of the biosorbent. In acidic medium, the $\mathrm{H}^{+}$ions compete with the metal ions by the functional groups of the adsorbent materials, so that the adsorption is small. The higher the $\mathrm{pH}$ value, the lower the amount of $\mathrm{H}^{+}$ion in the solution, increasing the adsorption of the metals (Silva et al., 2013).

\section{Phytoremediation}

The use of plant species for cleaning polluted soils and wastewater called phytoremediation gained a great deal of interest from many researchers since the beginning of the beginning of the 2000s, as a more economical and environmentally friendly emerging technology for Moderate metal removal of contaminated water. Hyper accumulators are species capable of accumulating metals at higher levels than those typically measured in plants without the accumulation capacity (Basile et al., 2012).

Macrophytes are essential core parts of aquatic environments, not only as a food source and habitat for aquatic invertebrates and fish, but also because they have the function of accumulating heavy metals. Submerged macrophytes have the ability to concentrate heavy metals due to its big surface area (Pandey, 2016). Many submerged species of macrophytes, such as Potamogeton spp., Elodea nuttallii and Hydrilla verticillata 
were used to verify their accumulation capacity, and many results were entirely satisfactory. In this way, it is possible to affirm that submerged macrophytes can be used to remove endangered metals from aquatic ecosystems. A species of microalgae, Spirulina platensis, can be used in the process of biosorption of toxic metals, being quite efficient for chromium (VI) biosorption (Xing et al., 2013).

This sorption of chrome from an aqueous solution onto Erythrina variegata orientalis leaf powder can be investigated in batch operations. The level of chrome biosorption increased about $12.2 \%$ with decreased biological sorbent size to $45 \mu \mathrm{m}$ for a dose of 30 g.L-1 . On the other hand, sorption capacity decreased from $99.1 \%$ to $45.5 \%$ with the initial chrome concentration variation of $22.5 \%$ to $180 \mathrm{mg} \cdot \mathrm{L}^{-1}$. The biosorption peak was reached with a pH value of 3 (Xing et al., 2013; Aditya et al., 2012).

Macrophytes have been used as an object of study by several authors who aim to evaluate their capacity in wastewater treatment due to their high growth rates. Thus, according to them, aquatic macrophytes have a high capacity to store nutrients in biomass, as well as high primary productivity, generally considered more efficient to the treatment of effluent. A species of microalgae, Spirulina platensis, can be used in the process of biosorption of toxic metals, being quite efficient for chromium (VI) biosorption (Wei et al., 2017).

Endophytes are outstanding bio-resources for enhancing phytoremediation efficiency. However, for phytoremediation to become a more credible and predictable option, a thorough understanding of plant-endophyte interactions illustrated in following Figure 4 (Feng et al., 2017).

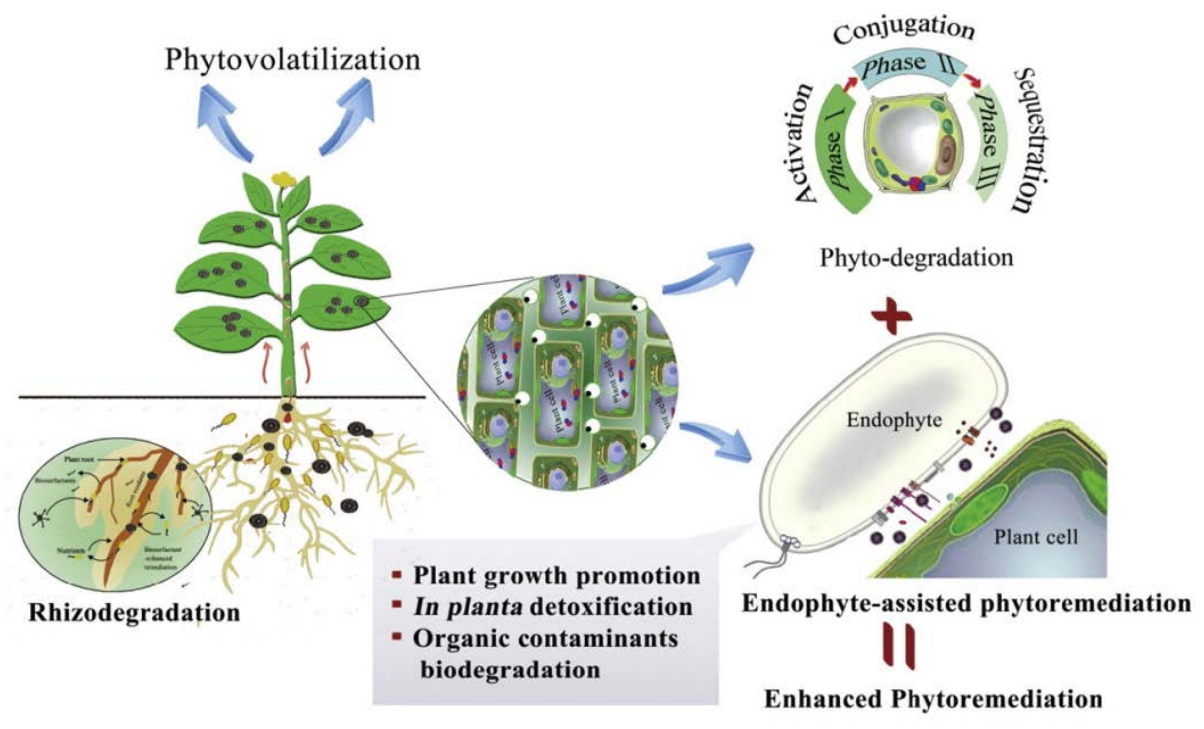

Figure 4. The plant-endophyte interaction) (Feng et al., 2017) (Copyright(C) 2017, Science of the Total).

Algae can accumulate metals on its external wall employing physical, chemical and biological mechanisms. For this reason, there is the possibility of use in treatment of wastewater The microalgae Spirulina platensis, for example, has presented an excellent ability to remove metal ions from aqueous solutions (Table 1). 
Table 1. Removal efficiency of $\mathrm{Cr}^{+6}$ by Spirulina platensis.

\begin{tabular}{|l|l|}
\hline Reaction time (h) & \% of remotion Cr (VI) \\
\hline Up to $4 \mathrm{~h}$ & About $50 \%$ \\
\hline Between $4 \mathrm{~h}$ and $24 \mathrm{~h}$ & Between $50 \%$ and $60 \%$ \\
\hline
\end{tabular}

Source: Dal Magro et al. (2013).

Dal Magro et al. (2013), proved that the high chromium (VI) concentration at low levels of biosorbent could compromise the process, reducing the potential of metal uptake by biomass, and there may be saturation of the capacity of the biosorption due to the saturation of the active sites in the cell wall.

Hexavalent chromium can present as chromate in the anionic form $\left(\mathrm{CrO}_{4}\right)^{2}$. In aqueous solution, chromium may present in the anionic form with chromate anions $\left(\mathrm{CrO}_{4}\right)^{2-}$ and dichromate $\left(\mathrm{Cr}_{2} \mathrm{O}_{7}\right)^{2-}$, in which chromium has an oxidation state +6 . With the $\mathrm{pH}$ decrease, functional groups such as amine and carbonyl provide positively charged cell surfaces, favoring the biosorption of metals present as anionic species. The drop in adsorption capacity at $\mathrm{pH}$ above 5.0 is due to the formation of hydrated metal complexes and electrostatic changes in the algae surface (Šillerová et al., 2013).

Giri et al. (2012) have chosen to measure the effect of using activated carbon derived from the ground and treated biomass of the species Eichhornia crassipes on chrome removal. The results showed metallic removals above $70 \%$, reaching up to indices higher than $90 \%$ of removal efficiency (Table 2). The results also revealed that increased adsorption capacity with increased temperature indicates that adsorption is a naturally endothermic process.

Table 2. Removal of Cr (VI) depending on the temperature.

\begin{tabular}{|c|c|c|c|}
\hline \multirow{2}{*}{$\begin{array}{c}\text { Temperature } \\
\left({ }^{\circ} \mathbf{C}\right)\end{array}$} & \multicolumn{3}{|c|}{ \% of remotion Cr (VI) } \\
\cline { 2 - 4 } & $\mathbf{1 0} \mathbf{~ m g / L}$ & $\mathbf{5 0} \mathbf{~ m g} / \mathbf{L}$ & $\mathbf{1 0 0} \mathbf{~ m g} / \mathbf{L}$ \\
\hline $25^{\circ} \mathrm{C}$ & Between $75 \%$ and $80 \%$ & Between $75 \%$ and $80 \%$ & Between $75 \%$ and $80 \%$ \\
\hline $45^{\circ} \mathrm{C}$ & Between $80 \%$ and $85 \%$ & Between $85 \%$ and $90 \%$ & Between $85 \%$ and $80 \%$ \\
\hline $55^{\circ} \mathrm{C}$ & Between $85 \%$ and $90 \%$ & Between $88 \%$ and $80 \%$ & Between $90 \%$ and $95 \%$ \\
\hline
\end{tabular}

Source: Giri et al. (2012).

According to Gaherwar and Kulkurani (2012) the chrome and zinc removal efficiency by the species Eichhornia crassipes is directly related to the time of exposure of the metal with the macrophyte. It was observed that the longer the exposure time, the higher the removal efficiency of the mentioned metals. This behavior was found even in different concentrations of metallic salts, reaching close to $100 \%$, with incubation periods of more than seven days.

Specifically, concerning the species Eichhornia crassipes, recent studies show that their application for the treatment of wastewater is quite comprehensive, in the sense of having a high capacity to remove various types of pollutants, are of organic or inorganic origin. Table 3 summarizes some applications (Rezania et al., 2015). 
Table 3. Metal removal from effluents.

\begin{tabular}{|c|c|c|}
\hline Effluent type & Metals & Eficiency \\
\hline $\begin{array}{l}\text { Residual water from water body } \\
\text { simulations }\end{array}$ & $(\mathrm{Cr}),(\mathrm{Cu})$ & \multirow{5}{*}{$\begin{array}{l}\text { In all cases, removal efficiency } \\
\text { above } 50 \% \text { was found for all } \\
\text { metals. }\end{array}$} \\
\hline Residual water from agriculture & $(\mathrm{Zn}),(\mathrm{Cu}),(\mathrm{Ni})$ & \\
\hline $\begin{array}{l}\text { Residual water from composting } \\
\text { process }\end{array}$ & $\begin{array}{l}(\mathrm{Cd}),(\mathrm{Zn}),(\mathrm{Fe}),(\mathrm{Mn}),(\mathrm{Pb}), \\
(\mathrm{Ni}),(\mathrm{Cr}),(\mathrm{Cu})\end{array}$ & \\
\hline Residual water from industrry & $(\mathrm{Zn}),(\mathrm{Cu}),(\mathrm{Cd})(\mathrm{Cr})$ & \\
\hline Artificials lakes & $(\mathrm{Zn}),(\mathrm{Cu}),(\mathrm{Pb}),(\mathrm{Cd})$ & \\
\hline
\end{tabular}

In another scientific work, Bind et al. (2019) investigated the percentage of removal of chromium (II), lead (II), arsenic (III) and chromium (VI) with the use of two types of macrophytes, Azolla filiculoides (floating) and Hydrilla verticillata (submerged). The maximum rate of lead removal (II) was achieved for the two biossorventes, Azolla sp. $(81.4 \%)$ and Hydrilla sp. (84.3\%) in tests lasting $4 \mathrm{~h}$ at a concentration of $10 \mathrm{mg} \mathrm{L}^{-1}$ of all metals studied. In addition, a decreasing removal behavior (\%) of chromium (II), lead (II), arsenic (III) and chromium was observed in all experiments, with maximum removal rates of $68.3 \%, 62.7 \%$ and $51.2 \%$ for Azolla sp. and $71.2 \%, 65.3 \%$ and $55.2 \%$ for Hydrilla sp., respectively. Another aspect observed refers to the minimum removal rate (\%) that was achieved in all experimental tests, in $25 \mathrm{mg} \mathrm{L}^{-1}$ (maximum) for all levels of heavy metals concentration. The removal efficiencies followed the sequence: $\mathrm{Pb}$ (II) $>\mathrm{Cu}$ (II) $>\mathrm{As}$ (III) $>$ $\mathrm{Cr}(\mathrm{VI})$, for the two sorbents. These metal removal results show the dependence of the removal of heavy metals by both biosorbents for the concentration of metals in aquatic environments.

\section{Treatment of aquatic environments with magnetite}

The mineral magnetite is considered chemically stable, infusible, slowly soluble in hydrochloric acid, and still presents the iron element in both oxidation states, $\mathrm{Fe}^{2+}$ and $\mathrm{Fe}^{3+}$. Its synthesis is made from three broad groups of physical, chemical, and microbial methods. However, the most widely used method is the co-precipitation of salts of $\mathrm{Fe}^{2+}$ and $\mathrm{Fe}^{3+}$ in the presence of a strong base, being the least expensive, simple, and ecologically correct. Still, there are several methodologies capable of synthesizing magnetite, such as partial reduction by heating of $\mathrm{Fe}^{3+}$ ions in the $\mathrm{N}_{2}$ atmosphere, gas condensation, and reduction by aerosol (Reddy et al., 2012).

A magnetic polymer or magnetic plastic is a non-metallic magnet material made from an organic polymer. For instance, the poly (1,3,5-triaminobenzene), showed a ferromagnetic phase up to the limit of $400{ }^{\circ} \mathrm{C}$, but only when oxidized with iodine (Silva et al., 2013).

\section{Metal removal for magnetite}

Among the nanomaterials, iron oxide nanoparticles, especially magnetite, hematite, and maghemite nanoparticles, can be used for the removal of ions of different toxic metals (Mirshahghassemi and Lead, 2015). The small size of the $\mathrm{Fe}_{3} \mathrm{O}_{4}$ nanoabsorbents is suitable for the diffusion of metallic ions of solution to the active sites of the surface of the adsorbents (Shi et al., 2015). In addition to their small size, iron oxide nanoparticles have been frequently employed in the removal of metals and organic compounds from aqueous solutions due to some peculiar features such as the large surface area, high relative reactivity and reduction capacity (Wang et al., 2014).

According to Karami's work (Karami, 2013), an electrochemical method of pulsed current was used, in which pure magnetite nanotubes were used, aiming the removal of 
several metals present in aqueous solution. The exposure time of the solutions containing metals with magnetite was initially observed, and the results can be observed (Table 4).

Table 4. Influence of contact time.

\begin{tabular}{|c|c|c|c|c|c|}
\hline $\begin{array}{c}\text { Contact } \\
\text { time (min) }\end{array}$ & $\begin{array}{c}\text { \% removal } \\
\text { Fe }\end{array}$ & $\begin{array}{c}\text { \% removal } \\
\text { Pb }\end{array}$ & $\begin{array}{c}\text { \% removal } \\
\text { Zn }\end{array}$ & $\begin{array}{c}\text { \% removal } \\
\text { Ni }\end{array}$ & $\begin{array}{c}\text { \% removal } \\
\mathbf{C u}\end{array}$ \\
\hline Up to 5 & About $90 \%$ & About $85 \%$ & About $80 \%$ & About $70 \%$ & About $70 \%$ \\
\hline Up to 40 & About $100 \%$ & About $100 \%$ & About $100 \%$ & About $100 \%$ & About $95 \%$ \\
\hline Over 80 & About $100 \%$ & About $100 \%$ & About $100 \%$ & About $100 \%$ & About $100 \%$ \\
\hline
\end{tabular}

Source: Karami (2013).

The influence of $\mathrm{pH}$ was also observed. The results showed that the best metal removal rates were observed with $\mathrm{pH}$ values above 6.0 for all metals mentioned above (Karami, 2013).

There is a vast list of applications for magnetic nanoparticles in various areas of science. Iron oxides are efficient bottom adsorbents and are part of a select group of inorganic compounds that are not environmentally aggressive. Highlights, there is the possibility of applying these compounds in the detection of illicit substances, in the classification of cells, in magnetic resonance imaging, among others (Al-Saad, 2012).

Various types of materials have been explored to adsorb metallic ions from aqueous solutions. However, the challenge was made for removing adsorbent metal ions. If the adsorbent central portion is magnetic, then separation is not hampered. The removal of metal ions using magnetic adsorbents recently drew attention to the treatment of industrial effluents (Zamboulis et al., 2011).

Several authors have developed numerous ways of synthesizing magnetic particles. One of them refers to the use of the tris (acetylacetonate)iron(III) or Fe(acac) 3 iron complex. Figure 5 shows a mechanism of preparation of magnetic particles from the use of this complex of octahedral geometry and reddish color (Sudo et al., 2010).

\section{$\mathrm{Fe}(\mathrm{acac})_{3}$ $+$ $\mathrm{CH}_{3} \mathrm{O}\left(\mathrm{CH}_{2} \mathrm{CH}_{2} \mathrm{O}\right)_{n} \mathrm{H}$}

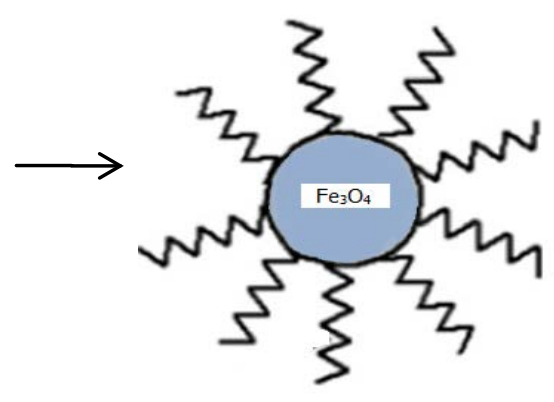

Figure 5. Magnetic particle formation (Sudo et al., 2010).

The absorption of metal ions in magnetite nanoparticles occurs by physicalchemical interactions, represented by electrostatic attractions, and the magnitude of comparative adsorption is confirmed throughout the equilibrium concentration range (Kalia et al., 2014). A fundamental modeling analysis can be used to stipulate the 
isothermal model that best describes experimental data. The Freundlich equation frequently describes adsorption data in a restricted concentration range, generally suitable for a medium whose surface is highly heterogeneous. According to Jin et al. (2018), a vital metal removal alternative, including chromium VI, part of the green synthesis of iron nanoparticles using extracts of eucalyptus leaves. According to this study, chromium (VI) is initially reduced to Chromium III, followed by co-precipitation of this chrome III with Fe (III). The results, under process optimization conditions, revealed a removal efficiency of more than $98 \%$ for Chrome VI and more than $84 \%$ for total chrome.

\section{Metal removal for magnetite and polymers}

Magnetic polymeric nanocomposites are of particular interest because they combine excellent magnetic properties with good stability and generally have favorable biocompatibility (Gong et al., 2012).

According to Culita et al. (2017), three new polyamine magnetic adsorbents were synthesized through the fixation of diamine, triamine, and tetraamine on the surface of magnetite nanoparticles coated with silica. Magnetic nanoparticles were initially synthesized with 3-chloropropylpyrroethoxyethylene (CITPS), giving rise to $\mathrm{Fe}_{3} \mathrm{O}_{4} @$ CIPTS. The following compounds have been synthesized: $\mathrm{Fe}_{3} \mathrm{O}_{4} @$ DETA (diethylene triamine), $\mathrm{Fe}_{3} \mathrm{O}_{4} @$ TETA (trimethylene tetraamine) and, $\mathrm{Fe}_{3} \mathrm{O}_{4} @ D A M P(1,3$ diamine propane). Figure 6 shows the application for the removal of copper.

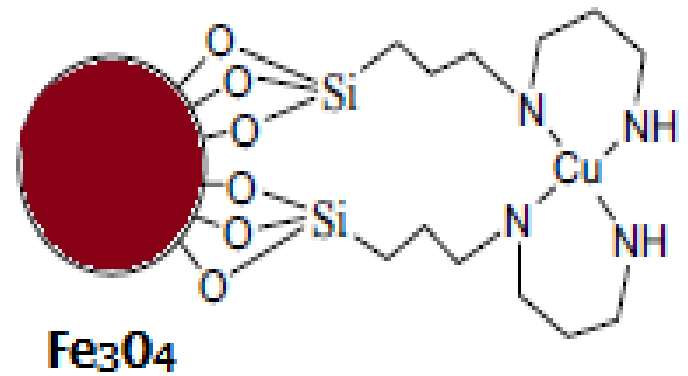

Figure 6. Chemical process for adsorption process.

In this process, sorption efficiency was reduced when the length of the polyamine chain immobilized in the adsorbent increased under ambient temperature conditions. In addition, the maximum adsorption rates were about $50 \mathrm{mg}^{-\mathrm{g}^{-1}}$ for functionalized adsorbent 1.3-diamine propane, close to $44 \mathrm{mg} \cdot \mathrm{g}^{-1}$ for functionalized diethylenetriamine, while for triethylenetetramine it was $39.2 \mathrm{mg} \mathrm{g}^{-1}$.

In the literature, there are numerous publications on the use of iron oxide particles synthesized in a variety of ways. Among so many others, there is the possibility of applying a compound synthesized from magnetite nanoparticles, graphene, and polyaniline sheets for the removal of $\mathrm{Cr}(\mathrm{VI})$ from water. According to Harijan and Chandra (2016), the equilibrium adsorptions were described by the Langmuir isothermal model and showed a maximum adsorption capacity of $153.54 \mathrm{mg}^{-1} \mathrm{~g}^{-1}$, considering a $\mathrm{pH} 6.5$ and temperature of $30{ }^{\circ} \mathrm{C}$. The kinetic data were adjusted by the pseudo-second-order model, and $86 \%$ of $\mathrm{Cr}$ (VI) removal was utilized in $20 \mathrm{~min}$. However, it was also found that $\mathrm{Cr}(\mathrm{VI})$ removal capacity decreased with increasing $\mathrm{pH}$ and ionic force. 
Ramachandran et al. (2017) applied magnetite with PANI for the removal of Cr(VI) present in groundwater. The findings revealed a reduction in the initial concentration of the samples tested to a tolerable 0.144 mg.L-1.

Polyaniline (PANI) is a conductive polymer that has a high ability to remove hexagonal chrome ions, since the granulated compound of polyaniline, which has a macroporous nature, indicates a high removal efficiency for metallic (Olad and Nabavi, 2007).

Sureshkumar et al. (2016) developed composites made from the mixture of magnetite and chitosan solution to form a hybrid nanocomposite. The amounts of chromium adsorbed by pure chitosan and the chitosan-magnetite combination were evaluated employing UV-Vis spectroscopy, and the results showed chromium removal rates of more than $92 \%$ from the water with the application of chitosan-magnetite, that is, much higher than the $29 \%$ obtained with the use of pure chitosan.

\section{Chrome removal for Eichhornia crassipes with magnetite}

Magnetite can also be synthesized by adding Eichhornia crassipes extracts, which ensures greater stability to the synthesized nanoparticles, according to Prabhakar et al. (2017). The results of this scientific paper showed that the nitrate and phosphate removal efficiency of wastewater reached indices above $70 \%$, with the application of these magnetic nanoparticles more stable.

A specific synthesis technique, known as 'green' synthesis, involves the use of a macrophyte (Eichhornia crasipses) combined with the simultaneous use of iron oxide III together with magnetite nanoparticles (Prabhakar et al., 2017). The $\mathrm{Cr}(\mathrm{VI})$ removal efficiency was compared with the results obtained with the isolated application of the macrophyte, as well as with the application also isolated from the magnetic particles. The results indicated that the metallic removal efficiency was not relevant to the use of only macrophyte extracts, reaching indexes of up to $20 \%$. However, there was a better yield with the combination of magnetic particles. Experiments in batches revealed about $90 \%$ of Cr (VI) were removed by Ec-Fe-NPS (Eichhornia crassipes extract + iron oxide (III) + magnetite nanoparticles), far superior to $20.4 \%$ with plant extracts isolated, and greater than $47.3 \%$ with the isolated application of iron oxide nanoparticles. The chromium VI removal mechanism results in the oxidation of Fe(II) to Fe(III), in addition to the reduction of chromium VI to chromium III. After proper $\mathrm{pH}$ adjustment, chromium (III) hydroxide and iron hydroxide (III) is formed, in addition to $\mathrm{Cr}_{\mathrm{x}} \mathrm{Fe}_{1-\mathrm{x}}(\mathrm{OH})_{3}$, which are then coprecipited, generating the final products (Wei et al., 2017).

However, there are numerous ways to modify biomass, in addition to the use of magnetite, in order to increase the removal efficiency of toxic substances present in water. One of them is to modify the macrophytes with zinc oxide nanoparticles. As with other procedures for removing $\mathrm{Cr}(\mathrm{VI})$ from water, the removal mechanism also involves reducing this hexavalent chrome into trivalent chrome. With this procedure, $\mathrm{Cr}(\mathrm{VI})$ removal may be greater than $95 \%$ (Yu et al., 2018).

\section{Conclusions}

Considering that metals in effluents may have a high potential for environmental degradation, research on efficient methods of removing chromium and other metals present in aquatic environments has a degree of immeasurable relevance.

The use of the Eichhornia crassipes macrophyte is defended by several scholars according to its ease of obtaining, but mainly by the satisfactory results of removal of metallic ions, although there is a marked dependence on some factors, such as dosage, contact time, initial concentration and the biosorbent, $\mathrm{pH}$ and temperature. 
Magnetic nanoparticles have been shown a large amount of applications in a large variety of scientific fields. The use of iron oxide particles for the removal of metals in effluents is justified by the fact that they are low-cost adsorbents and are not toxic to the environment, besides the elapsed efficiency of adsorption of metallic ions, in several concentration ranges.

The use of polymeric nanocomposites is based on the biocompatibility of these composites, the excellent magnetic properties and the stability of magnetic particles, thus characterizing an excellent option for the removal of organic and inorganic pollutants present in water.

The combination of biosorption techniques with the application of nanoparticles and/or polymeric nanocomposites for chrome (VI) removal presents enormous potential and represents an excellent alternative, which must be widely explored. There are many positive perspectives on the application of this technique in environments full of the most diverse types of pollutants of the aquatic environments, be they inorganic or organic pollutants, with rates of neutralization of contaminants above $80 \%$. It is a technique that is not aggressive to the environment and does not require huge financial investments, which makes it an excellent alternative to waste water treatment.

\section{Acknowledgements}

The authors gratefully acknowledge support for the permits granted by Elsevier (501600502) and also John Wiley and Sons (4914370287348), with information of great relevance on the central theme of this work, which enriched the present paper.

\section{Conflicts of interest}

The authors declare that have no conflict of interests.

\section{References}

Aditya, G. V. V.; Pujitha, B. P.; Babu, N. C.; Venkateswarlu, P. Biosorption of chromium onto Erythrina variegata orientalis leaf powder. Korean Journal of Chemical Engineering, v. 29, n. 1, p. 64-71, 2012. https:/doi.org/10.1007/s11814-011-0139-9

Al-Saad, K. A.; Amr, M. A.; Hadi, D. T.; Arar, R. S.; AL-Sulaiti, M. M.; Abdulmalik, T. A.; Alsahamary, N. M.; Kwak, J. C. Iron oxide nanoparticles: Applicability for heavy metal removal from contaminated water. Arab Journal of Nuclear Sciences and Applications, v. 45, p. 335-346, 2012.

Basile, A.; Sorbo S.; Conte, B.; Cobianchi, R. C.; Trinchella, F.; Capasso, C.; Carginale, V. Toxicity, accumulation, and removal of heavy metals by three aquatic macrophytes. International Journal of Phytoremediation, v. 14, p. 374-387, 2012. https://doi.org/ 10.1080/15226514.2011.620653

Bind, A.; Goswami, S.; Prakash, V. Comparative analysis of floating and submerged macrophytes for heavy metal (copper, chromium, arsenic and lead) removal: Sorbent preparation, characterization, regeneration and cost estimation. Geology, Ecology, and Landscapes, v. 2, p. 61-72, 2018. https://doi.org/10.1080/24749508.2018.1452460

Bind, A.; Kushwaha, G.; Devi, S.; Goswani; B. S.; Prakash, V. Biosorption valorization of floating and submerged macrophytes for heavy-metal removal in a multi-component system. Applied Water Science, v. 9, p. 95-99, 2019. https://doi.org/10.1007/s13201019-0976-y 
Culita, D. C.; Simonescu, C. M.; Patescu, R. E.; Preda, S.; Stanica, N.; Munteanu, C. U.; Oprea, O. Polyamine functionalized magnetite nanoparticles as novel adsorbents for $\mathrm{Cu}$ (II) removal from aqueous solutions. Journal of Inorganic and Organometallic Polymers and Materials, v. 27, p. 490-502, 2017. https://doi.org/10.1007/s10904-016-0491-7

Dal Magro, C.; Deon, M. C.; Thomé, A.; Piccin, J. S.; Colla, L. M. Biossorção passiva de cromo (VI) através da microalga Spirulina platensis. Química Nova, v. 36, no. 8, p. 1139-1145, 2013. https://doi.org/10.1590/S0100-40422013000800011

El-Taweel, Y. A.; Ehssan, M.; Nassef, E. M.; Elkheriany, I.; Sayed, D. Removal of Cr(VI) ions from waste water by electrocoagulation using iron electrode. Egyptian Journal of Petroleum, v. 24, p. 183-192, 2015. https://doi.org/10.1016/j.ejpe.2015.05.011

Feng, N.; Yu, J.; Zhao, H.; Cheng, Y.; Mo, C.; Cai, Q.; Li, Y.; Wong, M. Efficient phytoremediation of organic contaminants in soils using plant-endophyte partnerships. Science Total Environmental, v. 83, p.352-368, 2017. https://doi.org/10.1016/ j.scitotenv.2017.01.075

Gaherwar, S.; Klkurani P. Studies on removal of toxic heavy metals from water by Eichhornia crassipes. Indian Journal of Scientific Research, v. 3, no. 2, p. 99-103, 2012.

Giri, A. K.; Patel, R.; Mandal, S. Removal of Cr(VI) from aqueous solution by Eichhornia crassipes root biomass-derived activated carbon. Chemical Engineering Journal, v. 185/186, p. 71-81, 2012. https://doi.org/10.1016/j.cej.2012.01.025

Gong, J.; Wang, X.; Shao, X.; Yuan, S.; Yang, C.; Hub, X. Adsorption of heavy metal ions by hierarchically structured magnetite-carbonaceous sphere. Talanta, v. 101, p. 45-52, 2012. https://doi.org/10.1016/j.talanta.2012.08.035

Harijan, D. K. L.; Chandra, V. Magnetite/graphene/polyaniline composite for removal of aqueous hexavalent chromium. Journal of Applied Polymer Science, v. 133, no. 39, p. 44002-44009, 2016. https://doi.org/10.1002/app.44002

Jimenez, R. S.; Dal Bosco, S. M.; Carvalho, W. A. Heavy metals removal from wastewater by the natural zeolite scolecite: Temperature and $\mathrm{pH}$ influence in single-metal solutions. Química Nova, v. 27, no. 5, p 734-738, 2004. https://doi.org/10.1590/S010040422004000500011

Jin, X.; Liu, Y.; Tan, J.; Owens, G.; Chen, Z. Removal of Cr(VI) from aqueous solutions via reduction and absorption by green synthesized iron nanoparticles. Journal of Cleaner Production, v. 176, p. 929-936, 2018. https://doi.org/10.1016/j.jclepro.2017.12.026

Kalia, S.; Kango, S.; Kumar, A.; Haldorai, Y.; Kumari, B.; Kumar, R. Magnetic polymer nanocomposites for environmental and biomedical applications. Colloid and Polymer Science, v. 292, p. 2025-2052, 2014. https://doi.org/10.1007/s00396-014-3357-y

Karami, H. Heavy metal removal from water by magnetite nanorods. Chemical Engineering Journal, v. 219, p. 209-216, 2013. http://doi.org/10.1016/j.cej.2013.01.022

Kłos, A.; Gordzielik, E.; Jóźwiak, M.; Rajfur, M. Sorption of cadmium and zinc in selected species of epigeic mosses. Bulletin Environmental Contamination and Toxicology, v. 92, no. 3, p. 323-328, 2014. https://doi.org/10.1007/s00128-014-1210-0

Kong, D.; Zhang, F.; Wang, K.; Ren, Z.; Weidong, Z. Fast removal of $\operatorname{Cr}(\mathrm{VI})$ from aqueous solution using $\mathrm{Cr}(\mathrm{VI})$-imprinted polymer particles. Industrial \& Engineering Chemical Research, v. 53, no. 11, p. 4434-4441, 2014. https://doi.org/10.1021/ie403484p 
Kumari, M.; Pittman, C. U.; Mohan, D. Heavy metals [chromium (VI) and lead (II)] removal from water using mesoporous magnetite $\left(\mathrm{Fe}_{3} \mathrm{O}_{4}\right)$ nanospheres. Journal of Colloid and Interface Science, v. 442, p. 120-132, 2015. https://doi.org/10.1016/j.jcis.2014.09.012

Lee, J. D. Química inorgânica não tão concisa. 5. ed. São Paulo: Edgard Blücher, 1999.

Mirshahghassemi, S.; Lead, J. R. Oil recovery from water under environmentally relevant conditions using magnetic nanoparticles. Environmental Science \& Technology, v. 49, p. 11729-11736, 2015. http://doi.org/10.1021/acs.est.5b02687

Olad A.; Nabavi, R. Application of polyaniline for the reduction of toxic $\mathrm{Cr}(\mathrm{VI})$ in water. Journal of Hazard Materials, v. 147, p. 845-851, 2007. https://doi.org/10.1016/ j.jhazmat.2007.01.083

Pandey, V.C. Phytoremediation efficiency of Eichhornia crassipes in fly ash pond. International Journal Phytoremediation, v. 18, no. 5, p. 450-452, 2016. https://doi.org/10.1080/15226514.2015.1109605

Prabhakar, R.; Ranjan, S.; Samadder, J. Aquatic and terrestrial weed mediated synthesis of iron nanoparticles for possible application in wastewater remediation. Journal of Cleaner Production, v. 168, p. 1201-1210, 2017. https://doi.org/10.1016/j.jclepro.2017.09.063

Preuss, H. G.; Echard, B.; Perricone, N. V.; Bagchi, D.; Yasmin, T; Stohs, S. J. Comparing metabolic effects of six different commercial trivalent chromium compounds. Journal of Inorganic Biochemistry, v. 102, no. 11, p. 1986-1990, 2008. https://doi.org/10.1016/ j.jinorgbio.2008.07.012

Ramachandran, A.; Prasankumar, T.; Sivaprakash, S.; Wiston, B. R.; Biradar, S.; Jose, S. Removal of elevated level of chromium in groundwater by the fabricated PANI/ $\mathrm{Fe}_{3} \mathrm{O}_{4}$ nanocomposites. Environmental Science and Pollution Research, v. 24, no. 8, p. 74907498, 2017. https://doi.org/10.1007/s11356-017-8465-z

Reddy, L. H.; Arias, J. L.; Nicolas, J.; Couvreur, P. Magnetic nanoparticles: Design and characterization, toxicity and biocompatibility, pharmaceutical and biomedical applications. Chemical Reviews, v. 112, no. 11, p. 5818-5878, 2012. https://doi.org/ 10.1021/cr300068p

Rezania, S.; Ponraj, M.; Talaiekhozani, A.; Mohamad, S. M.; Din, M. F. Md.; Taib, S. M.; Sabbagh, F.; Sairana, F. Md. Perspectives of phytoremediation using water hyacinth for removal of heavy metals, organic and inorganic pollutants in wastewater. Journal of Environmental Management, v. 163, p.125-133, 2015. https://doi.org/10.1016/ j.jenvman.2015.08.018

Rodrigues, R. F.; Trevenzoli, R. L.; Santos, L. R. G.; Leão, V. A.; Botaro, V. R. Adsorção de metais pesados em serragem de madeira tratada com ácido cítrico. Engenharia Sanitária e Ambiental, $\quad$ v. 11, no. 1, p. 21-26, 2006. https://doi.org/10.1590/S141341522006000100004

Santander, P.; Morales, D.; Rivas, B. L.; Kabay, N.; Yilmaz, I.; Kuşku, Ö.; Yuksel, M.; Bryjak, M. Removal of $\mathrm{Cr}(\mathrm{VI})$ from aqueous solution by a highly efficient chelating resin. Polymer Bulletin, v. 74, p. 2033-2044, 2017. https://www.doi.org/10.1007/s00289-016-1824-y

Shadreck, M.; Mugadza, T. Chromium, an essential nutrient and pollutant: A review. African Pure Applied Chemistry, v. 7, no. 9, p. 310-317, 2013. https://doi.org/ 10.5897/AJPAC2013.0517 
Shi, J.; Li, H.; Lu, H.; Zhao, M. X. Use of carboxyl functional magnetite nanoparticles as potential sorbents for the removal of heavy metal ions from aqueous solution. Journal of Chemical and Engineering Data, v. 60, p. 2035-2041, 2015. https://doi.org/10.1021/ je5011196

Šillerová, H.; Komárek, M.; Chrastný, V.; Novák, M.; Vaněk, A.; Drábek, O. Brewers draff as a new low-cost sorbent for chromium (VI): Comparison with other biosorbents. Journal of Colloid and Interface Science, v. 396, p. 227-233, 2013. https://doi.org/10.1016/ j.jcis.2013.01.029

Silva, K. M. D.; Rezende, L. C. S. H.; Silva, C. A.; Bergamasco, R.; Gonçalves, D. S. Caracterização físico-química da fibra de coco verde para a adsorção de metais pesados em efluente de indústria de tintas. Engevista, v.15, p.43-50, 2013. https://doi.org/10.22409/engevista.v15i1.387

Sudo, A.; Hirayama, S.; Endo, T. Highly efficient catalysts-acetylacetonato complexes of transition metals in the 4th period for ring-opening polymerization of 1,3-benzoxazine. Journal of Polymer Science: Part A: Polymer Chemistry, v. 48, no. 2, p. 479-484, 2010. https://doi.org/10.1002/pola.23810

Sureshkumar, V.; Kiruba Daniel, S. C. G.; Ruckmani, K.; Sivakumar, M. Fabrication of chitosan-magnetite nanocomposite strip for chromium removal. Applied Nanoscience, v. 6, p. 277-285, 2016. https://doi.org/10.1007/s13204-015-0429-3

Wang, Y.; Fang, Z.; Liang, B.; Tsang, E. P. Remediation of hexavalent chromium contaminated soil by stabilized nanoscale zero-valent iron prepared from steel pickling waste liquor. Chemical Engineering Journal, v.247, p.283-290, 2014. https://doi.org/10.1016/j.cej.2014.03.011

Wei, Y.; Fang, Z.; Zheng, L.; Tsang, E. P. Biosynthesized iron nanoparticles aqueous extracts of Eichhornia crassipes and its mechanism in the hexavalent chromium removal. Applied Surface Science, v. 399, p. 322-329, 2017. https://doi.org/10.1016/j.apsusc.2016.12.090

Xing, W.; Wu, H.; Hao, B.; Huang, W.; Liu, G. Bioaccumulation of heavy metals by submerged macrophytes: looking for hyperaccumulators in eutrophic lakes. Environmental Science Technology, v. 47, no. 9, p. 4695-4703, 2013. http://www.doi.org/10.1021/es303923w

Yu, J.; Jiang, C.; Guan, Q.; Ning, P.; Gu, J.; Chen, Q.; Zhang, J.; Miao, R. Enhanced removal of $\mathrm{Cr}(\mathrm{VI})$ from aqueous solution by supported $\mathrm{ZnO}$ nanoparticles on biochar derived from waste water hyacinth. Chemosfere, v. 195, p. 632-640, 2018. https://doi.org/10.1016/ j.chemosphere.2017.12.128

Zamboulis, D.; Peleka, E. N.; Lazaridis, N. K. M. Metal ion separation and recovery from environmental sources using various flotation and sorption techniques. Journal of Chemical Technology and Biotechnology, v. 86, p.335-344, 2011. https://doi.org/ $10.1002 /$ jctb. 2552

License information: This is an open-access article distributed under the terms of the Creative Commons Attribution License, which permits unrestricted use, distribution, and reproduction in any medium, provided the original work is properly cited. 